\title{
ANALISIS FAKTOR-FAKTOR YANG MEMPENGARUHI PERILAKU SEKS PRANIKAH PADA REMAJA
}

\author{
Endang Dwi Ningsih, Ratna Indriati \\ STIKES PANTI KOSALA SURAKARTA, Sukoharjo, Jawa Tengah, Indonesia
}

\begin{abstract}
Abstrak
Latar Belakang. Perilaku seks pranikah masih mendominasi perdebatan dari sisi moral, psikologis dan fisik. Seks pranikah pada remaja berkaitan dengan rendah penggunaan kontrasepsi dan remaja cenderung memiliki banyak pasangan seksual pada usia yang lebih dini. Seks yang tidak aman merupakan faktor resiko terpenting kedua bagi timbulnya kecacatan dan kematian. Seks pranikah pada remaja mengalami peningkatan selama abad ke-20. Terkait hal di atas, maka perlu untuk melakukan penelitian tentang hubungan antara harga diri, religiusitas dan tingkat pengetahuan kesehatan reproduksi dengan perilaku seks pranikah pada remaja.

Tujuan Penelitian. Untuk menganalisis faktor-faktor yang mempengaruhi perilaku seks pranikah pada remaja.

Subyek Penelitian: Responden penelitian adalah mahasiswa AKPER PANTI KOSALA sejumlah 219 orang.

Hasil Penelitian. Dari uji multivariat diperoleh hasil: ada hubungan harga diri dengan perilaku seks pranikah $(p=0,041 ; p<0,05)$, ada hubungan religiusitas dengan perilaku seks pranikah $(p=0,020 ; p<0,005)$, ada hubungan tingkat pengetahuan kesehatan reproduksi dengan perilaku seks pranikah $(p=0,017 ; p<0,05)$.

Kesimpulan. Bahwa variabel harga diri, religiusitas dan tingkat pengetahuan kesehatan reproduksi secara bersama-sama berpengaruh terhadap perilaku seks pranikah dengan nilai Nagelkerke $R$ Square sebesar $21,9 \%$ dan sisanya yang $78,1 \%$ dipengaruhi variabel lain yang belum diteliti.
\end{abstract}

Kata kunci: harga diri, perilaku seks pranikah, religiusitas, tingkat pengetahuan, kesehatan reproduksi

\section{ANALYSIS OFINFLUENCING FACTORS PREMARITAL SEX BEHAVOR IN ADOLESCENTS}

Background. The premarital sexual behavior is still dominating the debate in terms of morality, psychological, and physicaly. The premarital sex behavior in adolescents is associated with the low rate of contraceptive uses and they are tend to have many sexual partners at an earlier ages. Unsafe sex is the second most important of the risk factor for disability and death. The premarital sex behavior in adolescents increased during 20th century. Related to the above, it is necessary research conducted on the relation the self-esteem, the religiousity and the level of reproductive health knowledge with the premarital sexual behavior in the adolescents.

Research Objectives. To analyze the factors that influence premarital sex behavior in adolescents.

Research Subjects. The respondents were 219 AKPER Panti Kosala students.

Results. By the multivariate tests that show the result there was any a relation between the self-esteem with the premarital sexual behavior $(p=0.041 ; p<0.05)$, there was any a relation between the religiousity with the premarital sexual behavior $(p=0.020$; $p<0.005)$, there was any a relation between the reproductive health knowledge with the premarital sexual behavior $(p=0.017 ; p<0.05)$.

Conclusion. The variables of the self-esteem, religiousity and the level of reproductive health knowledge are having affect of the premarital sexual behavior with the Negelkerke $R$ Square value is $21.9 \%$ and the remain of $78.1 \%$ that influenced by other variables have not examined yet. 
Keywords: the self-esteem, the religiousity and the level of the reproductive health knowledge and the premarital sexual behavior

Korespondensi: Endang Dwi Ningsih. STIKES PANTI KOSALA SURAKARTA. Jalan Raya Solo - Baki KM. 4 Gedangan, Grogol, Sukoharjo, Jawa Tengah.

Email: dwiningsih_e@yahoo.com

\section{LATAR BELAKANG}

Masa remaja merupakan masa transisi menuju kedewasaan. Tingkat berpikir yang belum matang menyebabkan perilaku remaja cenderung dapat menyimpang dari norma-norma yang ada. Perilaku seksual pranikah remaja, masih mendominasi perdebatan dari sisi moral, psikologis dan fisik. Seks pranikah remaja menjadi masalah serius karena berkaitan dengan rendahnya penggunaan kontrasepsi dan remaja cenderung memiliki banyak pasangan seksual jika mulai berhubungan seks pranikah pada usia yang lebih dini. Seks yang tidak aman merupakan faktor resiko terpenting kedua bagi timbulnya kecacatan dan kematian. Seks pranikah pada remaja mengalami peningkatan selama abad ke-20. Usia remaja mulai berhubungan seks bervariasi di tiap-tiap negara. Studi tentang perilaku seks pranikah remaja, memperoleh hasil sekitar $25 \%$ - $51 \%$ remaja telah berhubungan seks pranikah. Hasil Survei Kesehatan Reproduksi Remaja Indonesia (SKRRI) tahun 2007 menunjukkan sebesar 6,4\% remaja laki-laki dan 1,3\% remaja perempuan telah melakuan hubungan seks pranikah (Rahyani et al., 2012).

Beberapa pakar menyatakan, aktivitas seksual pranikah selalu membawa gangguan psikologis dan penyesalan berkepanjangan, terlebih jika mengalami kehamilan, rasa malu dan perasaan bersalah yang berlebihan dapat dialami remaja. Apalagi jika kehamilan tersebut diketahui orang tua.
Bahkan cenderung mengakibatkan suatu tindak kekerasan yang traumatik terhadap anak. Hal ini menambah tekanan psikologis yang berat yang mengarah pada depresi dan rasa tertekan yang mendalam (Kusmiran, 2012).

Penelitian menunjukkan bahwa harga diri akan mempengaruhi proses berfikir dan bertingkah laku. Munculnya harga diri membuat remaja tidak mudah ceroboh melakukan tindakan yang dapat merendahkan harga dirinya dan bisa mengontrol dorongan perilaku seksualnya (Hidayat, 2013). Harga diri adalah penilaian individu terhadap hasil yang dicapai, dengan cara menganalisis seberapa jauh perilaku individu tersebut sesuai dengan ideal diri, yang dapat diperoleh melalui orang lain dan diri sendiri (Sunaryo, 2013).

Semakin rendah religiusitas maka semakin tinggi intensitas perilaku seksual pranikah yang dilakukan remaja. Semakin baik pemahaman tingkat agama, maka perilaku seks pranikah remaja semakin baik dan sebaliknya (Irmawaty, 2013). Religiusitas/spiritualisasi adalah keyakinan dalam hubungannya dengan Tuhan. Semakin baik pengenalan seseorang pada Sang Maha Kuasa seharusnya semakin baik penalaran moralnya, salah satunya tentang perilaku seksual pranikah (Ambarwati dan Nasution, 2012).

Seks Pranikah pada remaja beresiko terhadap kehamilan dan penularan penyakit menular seksual. Kehamilan yang tidak direncanakan pada remaja perempuan dapat berlanjut pada 
aborsi dan pernikahan dini. Keduanya akan berdampak pada masa depan remaja tersebut, janin yang dikandung dan keluarganya, hal ini mencerminkan kurangnya pemahaman remaja tentang keterampilan hidup sehat, risiko hubungan seksual dan kemampuan untuk menolak hubungan yang tidak mereka inginkan (Kemenkes, 2012). Kekhawatiran akan penyakit menular pada alat reproduksi berkenaan dengan penyakit yang belum ada obatnya yang menyebabkan kematian cukup tinggi di Indonesia. Maka sangat perlu pengetahuan tentang kesehatan reproduksi bagi remaja yakni tentang keadaan sehat secara menyeluruh mencakup fisik, mental dan kehidupan sosial yang berkaitan dengan alat, fungsi serta proses reproduksi. Kesehatan reproduksi bukan saja kondisi bebas dari penyakit melainkan bagaimana seseorang memiliki kehidupan seksual yang aman (Rohan, et al., 2017).

\section{TUJUAN PENELITIAN}

Penelitian ini bertujuan untuk menganalisis faktor-faktor yang mempengaruhi perilaku seks pranikah pada remaja.

\section{DESAIN PENELITIAN}

Penelitian ini merupakan penelitian kuantitatif dengan desain korelasi yang melibatkan empat variabel untuk mengkaji hubungan variabel bebas (independent variable) dengan variabel terikat (dependent variable). Penelitian dilaksanakan di Akademi Keperawatan Panti Kosala Surakarta. Instrumen penelitian yang digunakan kuesioner, meliputi kuesioner tentang harga diri, religiusitas dan tingkat pengetahuan tentang kesehatan reproduksi dengan kategori tinggi dan rendah serta perilaku seks pranikah dengan kategori melakukan atau tidak. Analisa statistik dilakukan dengan program SPSS versi 18.0 menggunakan uji Chi Square dan analisa multivariat dengan uji regresi logistik. Nilai $p$ dianggap bermakna secara statistik jika $<0,05$.

\section{POPULASI, SAMPEL DAN TEKNIK SAMPLING}

Populasi dan sampel pada penelitian ini adalah mahasiswa Akademi Keperawatan Panti Kosala dan peneliti menggunakan tehnik pengambilan sampel dengan quota sampling yaitu mengambil sampel yang didasarkan atas pertimbangan tertentu.

\section{HASIL PENELITIAN}

Dapat dipaparkan sebagai berikut:

Tabel 1.

Karakteristik Responden

\begin{tabular}{lcc}
\hline Karakteristik & $\mathrm{f}$ & $\%$ \\
\hline Jenis kelamin: & & \\
Laki-laki & 55 & 25 \\
Perempuan & 164 & 75 \\
Tingkat/Kelas: & & \\
Tingkat I & 89 & 41 \\
Tingkat II & 47 & 21 \\
Tingkat III & 83 & 38 \\
\hline
\end{tabular}

Dari Tabel 1 menunjukkan bahwa sebagian besar responden berjenis kelamin perempuan berjumlah 164 orang $(75 \%)$ dan yang berjenis kelamin laki-laki berjumlah 55 orang (25\%). Sedangkan karakteristik berdasarkan tingkat/kelas, tingkat I sebanyak 89 orang (41\%), tingkat II sebanyak 47 orang $(21 \%)$ dan tingkat III sebanyak 83 orang (38\%). 
Tabel 2.

Distribusi Frekuensi Variabel Penelitian

\begin{tabular}{lcc}
\hline Variabel & $\mathrm{f}$ & $\%$ \\
\hline Harga diri: & & \\
Tinggi & 201 & 92 \\
Rendah & 18 & 8 \\
Religiusitas: & & \\
Tinggi & 198 & 90 \\
Rendah & 21 & 10 \\
Tingkat Pengetahuan: & \\
Tinggi & 202 & 92 \\
Rendah & 17 & 8 \\
Perilaku seks pranikah: & \\
Melakukan & 88 & 40 \\
Tidak melakukan & 131 & 60 \\
\hline
\end{tabular}

Tabel 2 menunjukkan responden pada variabel harga diri, kategori tinggi sejumlah 201 orang $(92 \%)$ sedang kategori rendah sejumlah 18 orang $(8 \%)$. Pada variabel religiusitas, responden kategori tinggi sejumlah 198 orang $(90 \%)$ sedang kategori rendah sejumlah 21 orang (10\%). Pada variabel tingkat pengetahuan tentang kesehatan reproduksi, responden kategori tinggi sejumlah 202 orang $(92 \%)$ dan kategori rendah sejumlah 17 orang (8\%). Pada Variabel perilaku seks pranikah, responden yang melakukan sebanyak 88 orang $(40 \%)$ sedang yang tidak melakukan sejumlah 131 orang $(60 \%)$.

Tabel 3.

Analisa Bivariat

\begin{tabular}{|c|c|c|c|c|c|c|c|}
\hline \multirow[b]{2}{*}{ Variabel } & \multicolumn{7}{|c|}{ Perilaku Seks Pranikah } \\
\hline & $\begin{array}{c}\text { Melakukan } \\
(\%)\end{array}$ & $\begin{array}{c}\text { Tidak } \\
(\%)\end{array}$ & $\begin{array}{c}\text { Total } \\
(\%)\end{array}$ & $P$ & OR & $\begin{array}{l}\text { Batas } \\
\text { bawah }\end{array}$ & $\begin{array}{l}\text { Batas } \\
\text { atas }\end{array}$ \\
\hline \multicolumn{8}{|l|}{ Harga Diri } \\
\hline Tinggi & $\begin{array}{c}72 \\
(36)\end{array}$ & $\begin{array}{l}129 \\
(64)\end{array}$ & $\begin{array}{c}201 \\
(100)\end{array}$ & 0,000 & 0,07 & 0,016 & 0,312 \\
\hline Rendah & $\begin{array}{l}16 \\
(89)\end{array}$ & $\begin{array}{c}2 \\
(11)\end{array}$ & $\begin{array}{c}18 \\
(100)\end{array}$ & & & & \\
\hline \multicolumn{8}{|c|}{ Religiusitas } \\
\hline Tinggi & $\begin{array}{c}70 \\
(35)\end{array}$ & $\begin{array}{c}128 \\
(65)\end{array}$ & $\begin{array}{c}198 \\
(100)\end{array}$ & 0,000 & 0,09 & 0,026 & 0,320 \\
\hline Rendah & $\begin{array}{l}18 \\
(86)\end{array}$ & $\begin{array}{c}3 \\
(14)\end{array}$ & $\begin{array}{c}21 \\
(100)\end{array}$ & & & & \\
\hline \multicolumn{8}{|c|}{$\begin{array}{l}\text { Tingkat } \\
\text { Pengetahuan }\end{array}$} \\
\hline Tinggi & $\begin{array}{c}72 \\
(36)\end{array}$ & $\begin{array}{l}130 \\
(64)\end{array}$ & $\begin{array}{c}202 \\
(100)\end{array}$ & 0,000 & 0,04 & 0,004 & 0,266 \\
\hline Rendah & $\begin{array}{c}16 \\
(94) \\
\end{array}$ & $\begin{array}{l}1 \\
(6)\end{array}$ & $\begin{array}{c}17 \\
(100) \\
\end{array}$ & & & & \\
\hline
\end{tabular}

Tabel 3 menunjukkan terdapat hubungan yang signifikan antara harga diri dengan perilaku seks pranikah, responden yang memiliki harga diri tinggi memiliki kemungkinan melakukan seks pranikah lebih rendah 0,07 kali daripada responden yang memiliki harga diri rendah $(\mathrm{OR}=0,07$; $p=0,000)$. Terdapat hubungan yang signifikan antara religiusitas dengan perilaku seks pranikah, responden yang memiliki religiusitas tinggi memiliki kemungkinan melakukan seks pranikah lebih rendah 0,09 kali daripada responden yang memiliki religiusitas rendah $(O R=0,09 ; \quad p=$ 0,000 ). Terdapat hubungan yang signifikan antara tingkat pengetahuan tentang kesehatan reproduksi dengan perilaku seks pranikah, responden yang memiliki tingkat 


$\begin{array}{lll}\text { pengetahuan } & \text { tinggi memiliki } & \text { dibanding responden yang tingkat } \\ \text { kemungkinan } & \text { melakukan seks } & \text { pengetahuannya rendah }(\mathrm{OR}=0,04 ; \\ \text { pranikah lebih } & \text { rendah } 0,04 \text { kali } & p=0,000) \text {. }\end{array}$

Tabel 4.

Analisa Multivariat Regresi Logistik

\begin{tabular}{lcccc}
\hline Variabel & $\mathrm{B}$ & $\mathrm{p}$ & $\mathrm{OR}$ & $\begin{array}{c}\text { Nagelkerke } \\
R \text { Square }\end{array}$ \\
\hline Harga Diri & $-1,701$ & 0,041 & 0,18 & \\
Religiusitas & $-1,619$ & 0,020 & 0,20 & 0,219 \\
Tingkat Pengetahuan & $-2,578$ & 0,017 & 0,08 & \\
\hline
\end{tabular}

Tabel 4 menunjukkan hubungan yang negatif dan signifikan antara harga diri dengan perilaku seks pranikah. Responden yang memiliki harga diri tinggi kemungkinan melakukan perilaku seks pranikah lebih rendah 0,18 kali daripada responden yang memiliki harga diri rendah $\quad(O R=0,18 ; \quad p=0,041)$. Terdapat hubungan yang negatif dan signifikan antara religiusitas dengan perilaku seks pranikah. Responden yang memiliki religiusitas tinggi memiliki kemungkinan melakukan perilaku seks pranikah lebih rendah 0,20 kali daripada responden yang memiliki religiusitas rendah $(\mathrm{OR}=0,20$; $p=0,020$ ). Terdapat hubungan yang negatif dan signifikan antara tingkat pengetahuan tentang kesehatan reproduksi dengan perilaku seks pranikah. Responden yang memiliki tingkat pengetahuan tinggi memiliki kemungkinan melakukan perilaku seks pranikah lebih rendah 0,08 kali daripada responden yang memiliki tingkat pengetahuan rendah (OR=0,08; $p=0,017$ ).

Pada uji multivariat menunjukkan nilai Nagelkerke $R$ Square sebesar $21,9 \%$ artinya bahwa variabel harga diri, religiusitas dan tingkat pengetahuan secara bersama-sama berkorelasi dengan perilaku seks pranikah dan memberi kontribusi sebesar $21,9 \%$ dalam pembentuk perilaku responden untuk melakukan perilaku seks pranikah dan sisanya yang $78,1 \%$ dipengaruhi variabel lain yang belum diteliti.

\section{PEMBAHASAN}

Berdasarkan Tabel 2 sebagian besar responden memiliki harga diri tinggi sebesar 92\%. Harga diri merupakan penilaian pribadi individu yang diekspresikan dalam sikap terhadap diri sendiri, bila memiliki harga diri tinggi berarti responden memiliki penerimaan dan penghargaan yang positif, tenang dan bertindak efektif dalam perilakunya. Individu yang memiliki harga diri tinggi adalah individu yang berkepribadian sehat, mampu mempertimbangkan akan sesuatu yang bernilai, konsisten terhadap persepsi dan pandangan hidupnya dan memiliki sosial kontrol yang baik (Susanto, 2018).

Dari hasil uji bivariat dapat diperoleh $p=0,000 ; \quad O R=0,07$ dan uji multivariat $p=0,041 ; \quad O R=0,18$ maka ada korelasi antara harga diri dengan perilaku seks pranikah, artinya semakin tinggi harga diri responden kemungkinan melakukan perilaku seks pranikah makin rendah karena memiliki pertimbangan yang bernilai, pandangan yang positif dan memiliki sosial kontrol yang baik. Hal ini dapat dilihat pada tabel 3 dari 201 orang yang memiliki harga diri tinggi, $64 \%$ responden tidak melakukan perilaku seks pranikah, hal ini sesuai dengan hasil 
penelitian Hidayat (2013) dengan judul pengaruh harga diri dan penalaran moral terhadap perilaku remaja berpacaran di SMKN 5 Samarinda bahwa harga diri dan penalaran moral memiliki pengaruh yang signifikan terhadap perilaku seksual remaja berpacaran $(p=0,000)$. Dari penelitian tersebut dinyatakan bahwa harga diri mempengaruhi proses berpikir dan bertingkah laku, munculnya harga diri membuat remaja tidak mudah ceroboh melakukan tindakan yang dapat merendahkan harga dirinya dan individu mampu mengontrol dorongan perilaku seksualnya.

Tabel 3 terdapat $36 \%$ orang yang memiliki harga diri tinggi tetapi telah melakukan perilaku seks pranikah, demikian halnya pada responden yang memiliki harga diri rendah $89 \%$ telah melakukan perilaku seks pranikah. Terkait hal di atas penelitian oleh Haryani D.S, Wahyuningsih dan Haryani K. (2015), menyampaikan bahwa dari survei yang dilakukan didapatkan alasan bahwa hubungan seksual pranikah tersebut sebagian besar karena ingin tahu/penasaran $(57,5 \%)$, terjadi begitu saja (38\%) dan dipaksa oleh pasangannya $(12,6 \%)$, maka hal ini mencerminkan kurangnya pemahaman remaja tentang ketrampilan hidup sehat, resiko hubungan seksual dan kemampuan menolak hubungan yang tidak diinginkan (Kemenkes, 2012).

Maka sangat penting peran orang tua dalam mengarahkan dan memberi pemahaman yang tepat pada putra putrinya, sebagaimana yang dinyatakan oleh Lestari, Ulfiana dan Suparmi (2013), bahwa sangat perlu pengetahuan tentang kesehatan reproduksi agar tidak berpengaruh buruk terhadap kesehatan remaja karena pengetahuan yang tidak lengkap dan tidak tepat tentang masalah seksual, terjadi penyalahgunaan seksual atau melakukan aborsi bagi remaja putri.

Berdasarkan Tabel 2 sebagian besar responden memiliki tingkat religiusitas tinggi sebesar $90 \%$. Religiusitas adalah bentuk keshalehan atau kepatuhan terhadap ajaran agama yang diyakini, merupakan bentuk visualisasi hubungan individu dengan kepercayaannya, menunjukkan apa yang dipahami oleh individu dan bagaimana dia melakukan atau melegitimasikan tindakannya (Santosa, 2011).

Dari hasil uji bivariat diperoleh $p=$ 0,$000 ; \quad O R=0,09$ dan dari uji multivariat $p=0,020 ; O R=0,20$ maka ada korelasi antara religiusitas responden dengan perilaku seks pranikah artinya semakin tinggi religiusitas/keshalehan responden kemungkinan melakukan perilaku seks pranikah makin rendah, hal ini dapat dilihat pada tabel 3 dari 198 orang yang memiliki harga diri tinggi, $65 \%$ responden tidak melakukan perilaku seks pranikah, penelitian serupa oleh Khairunnisa (2013), dengan judul hubungan religiusitas dan kontrol diri dengan perilaku seksual pranikah remaja MAN 1 Samarinda menyatakan ada hubungan yang signifikan antara religiusitas dan kontrol diri dengan perilaku seksual pranikah remaja. Penelitian serupa oleh Aryati (2016), dengan judul hubungan harga diri dan religiusitas dengan perilaku seks pranikah, hasil $R$ Square memberikan sumbangan efektif variabel bebas terhadap variabel terikat $9,4 \%$ dan sisanya yang $90,4 \%$ dipengaruhi faktor lain diluar penelitian.

Potter dan Perry (2010), menyatakan bahwa religiusitas atau pelayanan spiritual akan membantu individu untuk menentukan arti dan tujuan hidupnya, menjaga hubungan dengan orang lain sama baiknya dengan menjaga hubungan dengan sang penciptanya serta memiliki 
kepercayaan dan mencari hidup yang sangat berarti, oleh karenanya dengan religiusitas yang baik, seseorang akan bertindak dan berperilaku sesuai ajaran dan nilainilai yang diyakini. Tetapi pada Tabel 3 terdapat $35 \%$ orang yang memiliki religiusitas tinggi tetapi telah melakukan perilaku seks pranikah, juga pada responden yang memiliki religiusitas rendah $86 \%$ telah melakukan perilaku seks pranikah. Berdasarkan data hasil survey BKKBN dinyatakan ada $51 \%$ remaja yang sudah tidak perawan dari 1660 responden yang tersebar di 16 PT dan 97,05\% mengaku kehilangan keperawanan ketika masih kuliah (Hudaraja, 2018). Sebagaimana dinyatakan Potter dan Perry (2010), bahwa spiritual merupakan faktor penting yang membantu individu mencapai keseimbangan yang diperlukan untuk memelihara kesehatan dan kesejahteraan, sedang pada kutipan yang lain Potter dan Perry menyatakan bahwa setiap budaya dan kelompok masyarakat memiliki kumpulan peran dan norma tersendiri yang memberi petunjuk pada sikap seksual dan kesehatan seksual individu, norma-norma budaya mempengaruhi bagaimana individu mendapat pasangan, bagaimana mereka berhubungan dan seberapa sering melakukan hubungan seks. Kepercayaan individu dapat menentukan mereka melakukan atau tidak perilaku seksual tersebut. Jadi dapat disimpulkan bahwa perilaku seks pranikah remaja masih sering mendominasi perdebatan dari sisi moral, agama, psikologis dan fisik, karena pada kenyataannya para remaja/anak-anak mengetahui informasi tentang seks pada era informasi ini lebih banyak ketika berselancar di internet, TV kabel atau media sosial sehingga rasa ingin tahu remaja sangat sulit dibendung meskipun remaja tersebut memiliki spiritual yang baik. Terkait hal tersebut, sangat penting peran orang tua dan sekolah untuk dapat melakukan pencegahan (meminimalisir) dengan memberikan pengetahuan tentang: tumbuh kembang remaja, kehamilan, pendidikan seks, penyakit menular, kekerasan seksual dan cara menghindari (Lestari, Ulfiana dan Suparmi, 2013).

Berdasarkan Tabel 2 sebagian besar responden memiliki tingkat pengetahuan tentang kesehatan reproduksi kategori tinggi sebesar $92 \%$. Pengetahuan adalah domain yang sangat penting untuk terbentuknya tindakan/perilaku, perilaku yang didasari oleh pengetahuan akan lebih langgeng dari pada yang tidak didasari pengetahuan (Wawan dan Dewi, 2011). Demikian halnya disampaikan Notoatmodjo (2012), bahwa pengadopsian perilaku yang didasari pengetahuan dan kesadaran positif akan bersifat langgeng maka faktor pendidikan, usia, lingkungan dan sosial akan menentukan sejauhmana perilaku sehatnya.

Dari hasil uji bivariat diperoleh $p=$ 0,$000 ; \quad O R=0,004$ dan pada uji multivariat diperoleh $p=0,017 ; O R=0,08$ maka ada korelasi antara tingkat pengetahuan tentang kesehatan reproduksi dengan perilaku seks pranikah artinya semakin tinggi tingkat pengetahuannya kemungkinan melakukan perilaku seks pranikah makin rendah karena mampu melakukan pengendalian diri, hal ini dapat dilihat pada Tabel 3 dari 202 orang yang memiliki tingkat pengetahuan tinggi, $64 \%$ responden tidak melakukan perilaku seks pranikah, pengetahuan seseorang terbentuk melalui proses yang terus-menerus dan setiap saat akan mengalami reorganisasi karena adanya pemahaman yang baru, maka 
sangat perlu remaja diberikan pengetahuan baru untuk mereorganisasi pengetahuannya melalui pengalaman pribadi yang mampu meninggalkan kesan yang kuat untuk membentuk perilakunya, memberikan pengaruh dari orang yang dianggap penting karena individu cenderung memiliki sikap yang searah dengan orang yang dianggap penting dan memberi bimbingan yang benar dari pengaruh sosial budaya dan media massa.

Pada Tabel 3 terdapat $36 \%$ orang yang memiliki tingkat pengetahuan tinggi tetapi telah melakukan perilaku seks pranikah, juga pada responden yang memiliki tingkat pengetahuan rendah $94 \%$ telah melakukan perilaku seks pranikah. Sebagaimana disampaikan oleh Sembayang, Gultom dan Sidabutar (2011) bahwa faktor yang mempengaruhi perilaku seksual individu adalah dorongan seksual, kesehatan, psikis, pengetahuan seksual dan pengalaman seksual sebelumnya. Pengetahuan seksual yang salah dapat memimpin seseorang untuk berperilaku seksual yang salah dengan segala akibatnya, informasi yang salah menyebabkan pengertian dan persepsi remaja tentang seks menjadi salah pula. Maka beberapa cara untuk mengatasi perilaku seksual remaja yang dapat dilakukan oleh orang tua dan sekolah adalah: menyediakan informasi tentang pendidikan kesehatan yang akurat, memperbanyak akses pelayanan konseling kesehatan, menciptakan lingkungan keluarga yang kondusif dan informatif, pandangan bahwa seks tabu harus segera dikikis, justru para orang tua sesegera mungkin memberikan pemahaman yang tepat tentang seks.

Pada uji multivariat menunjukkan nilai Nagelkerke $R$ Square sebesar $21,9 \%$ artinya variabel harga diri, religiusitas dan tingkat pengetahuan secara bersama-sama berkorelasi dengan perilaku seks pranikah dan memberi kontribusi sebesar $21,9 \%$ dalam pembentuk perilaku responden untuk melakukan perilaku seks pranikah dan sisanya yang $78,1 \%$ dipengaruhi variabel lain yang belum diteliti. Pada Tabel 2 diperoleh data bahwa 40\% responden melakukan dan $60 \%$ tidak melakukan perilaku seks pranikah. Dari data $60 \%$ responden tidak melakukan perilaku seks pranikah ini menunjukkan bahwa variabel harga diri, religiusitas dan tingkat pengetahuan sangat berkontribusi dalam pembentukan perilaku remaja dan yang perlu mendapat perhatian adalah $40 \%$ responden yang telah melakukan perilaku seks pranikah yang disokong oleh sebagian responden yang memiliki harga diri, religiusitas dan tingkat pengetahuan tentang kesehatan reproduksi tinggi maupun rendah. Dari data kuesioner variabel perilaku seks pranikah dari 219 responden diperoleh gambaran secara rinci tentang perilaku yang ditunjukkan berikut ini: gemar membaca atau melihat gambar porno $5 \%$, berciuman dengan bibir $30 \%$, melakukan rangsangan dengan lawan jenis $15 \%$, pernah petting dengan lawan jenis $7 \%$, berciuman di leher dengan lawan jenis $17 \%$, melakukan hubungan seksual dengan lawan jenis $6 \%$, melakukan sentuhan untuk menimbulkan rangsangan $15 \%$, yang menyatakan pacaran harus melakukan hubungan seks $3 \%$, tidak mampu mengendalikan diri $12 \%$, yang menyatakan hubungan seks adalah wujud kasih sayang $6 \%$. Dari paparan tersebut dapat diperoleh informasi bahwa perilaku seks pranikah yang dilakukan responden tidak murni pada hubungan seksual dengan lawan jenis tetapi ada beberapa perilaku yang tidak berhubungan seksual 


\begin{abstract}
tetapi dikategorikan perilaku seksual sebagaimana yang disampaikan oleh Sebayang, Gultom dan Sidabutar (2011), maka yang harus menjadi perhatian dalam meningkatkan kesadaran remaja untuk tidak melakukan perilaku seks adalah dengan memantau dan membimbing perkembangan individu remaja, meminimalisir pengaruh dari eksternal dan masyarakat yang tidak baik, selain meningkatkan pemahaman remaja untuk memiliki harga diri yang tepat, religiusitas dan moral yang benar serta memiliki tingkat pengetahuan kesehatan reproduksi yang benarbenar diterapkan dalam hidup pribadi remaja.
\end{abstract}

\section{KESIMPULAN}

Terdapat hubungan yang signifikan antara harga diri, religiusitas dan tingkat pengetahuan tentang kesehatan reproduksi dengan perilaku seks pranikah. Uji multivariat menunjukkan nilai Nagelkerke $R$ Square sebesar $21,9 \%$ sehingga variabel harga diri, religiusitas dan tingkat pengetahuan secara bersama-sama berkorelasi dengan perilaku seks pranikah dan memberi kontribusi sebesar $21,9 \%$ dan sisanya yang $78,1 \%$ dipengaruhi variabel lain yang belum diteliti.

\section{SARAN}

Dibutuhkan peran orang tua dalam mengarahkan dan memberi pemahaman yang benar tentang masalah seksual menyangkut kesehatan reproduksi dan resiko penyalahgunaan seksual. Perlunya institusi pendidikan terus-menerus memberikan pendidikan kesehatan pada para remaja tentang resiko dan penyakit karena seks bebas.

\section{DAFTAR PUSTAKA}

Ambarwati, Fitri Respati dan Nita Nasution. 2012. Buku Pintar Asuhan

Keperawatan
Kesehatan Jiwa. Cakrawala IImu, Yogyakarta.

Aryati, Jeane. 2016. Hubungan Antara Harga Diri dan Religiusitas terhadap Perilaku Seksual Pranikah Pada Remaja.

https://repository.Usd.ac.id. Diakses 28 September 2019.

Haryani, D.S, Wahyuningsih dan Haryani K. 2015. Peran Orang Tua Berhubungan dengan Perilaku Seksual Pranikah Remaja di SMK N 1 Sendayu. https://scholar.google.co.id.

Diakses pada tanggal 27 Agustus 2019.

Hidayat, Khafri. 2013. Pengaruh Harga Diri dan Penalaran Moral terhadap Perilaku Seksual Remaja Berpacaran di SMK Negeri 5 Samarinda. http://ejournal.psikologi.fisipunmul.ac.id. Diakses pada tanggal 26 Agustus 2019.

Irmawaty, Lenny. 2013. Perilaku Seksual pada Mahasiswa. https://journal.unnes.ac.id.

Diakses pada tanggal 13 Agustus 2019.

Hudaraja, Arya. 2018. Kimcilisasi and Young Zaman Now. Diakses pada tanggal 28 Agustus 2019. https://books.google.co.id.

Khairunnisa, Ayu. 2013. Hubungan Religiusitas dan Kontrol Diri dengan Perilaku Seksual Pranikah Remaja di MAN 1 Samarinda.

http://ejournal.psikologi.fisip-

unmul.ac.id. Diakses pada tanggal 26 Juli 2019.

Kusmiran, Eny. 2012. Kesehatan Reproduksi Remaja. Salemba Medika, Jakarta.

Kemenkes. 2012. Situasi Kesehatan Reproduksi Remaja. https://www.google.com.

Diakses pada tanggal 5 September 2019.

Lestari, Tri Wiji, Elisa Ulfiana dan Suparmi. 2013. Buku Ajar 
Kesehatan Reproduksi Berbasis Kompetensi. EGC, Jakarta.

Notoatmojo, Soekidjo. 2012. Kesehatan Masyarakat IImu dan Seni. Rineka Cipta, Jakarta.

Potter, Patricia A. dan Anne G. Perry. 2010. Fundamental Keperawatan Edisi 7. Buku 2. Salemba Medika, Jakarta.

Rahyani, Yuni, et al. 2012. Perilaku Seks Pranikah Remaja. http://journal.fkm.ui.ac.id.

Diakses pada tanggal 26 Agustus 2019.

Rohan, Hasdianah Hasan, et al. 2017. Buku Kesehatan Reproduksi: Pengenalan Penyakit menular Reproduksi dan Pencegahannya. Intimedia, Malang.

Santoso, W. 2011. Sosiologi Feminimisme: Konstruksi Perempuan dalam industri Media. Diakses pada tanggal 11 Agustus 2019. https://books.google.co.id.
Sebayang, Wellina, Destyna Yohana Gultom, dan Eva Royani Sidabutar. 2018. Perilaku Seksual Remaja. Diakses pada tanggal 5 Agustus 2019. https://books.google.co.id.

Sunaryo. 2013. Psikologi Untuk Keperawatan Ed. 2. EGC, Jakarta.

Susanto, Ahmad. 2018. Bimbingan dan Konseling di Sekolah. Prenadamedia, Jakarta. Diakses pada tanggal 11 September 2019. https://books.google.co.id.

Wawan A. dan Dewi M. 2011. Pengetahuan, Sikap dan Perilaku Manusia. Nuha Medika, Yogyakarta. 